\title{
PERANCANGAN APLIKASI PEMBLOKIR IKLAN (ADVERTISEMENT) PADA BROWSER YANG BERBASIS ANDROID
}

\author{
Surya Mudti Salmat ${ }^{1}$, Harlinda ${ }^{2}$, dan Lilis Nurhayati ${ }^{3}$ \\ 1'suryamudti0128@gmail.com, ${ }^{2}$ harlinda@umi.ac.id, ${ }^{3}$ lilis.nurhayati@umi.ac.id ${ }^{1,2,3}$ Universitas Muslim \\ Indonesia
}

\begin{abstract}
Abstrak
Berkembang pesatnya teknologi mobile dalam beberapa tahun terakhir membuat segala keperluan pengguna bisa diperoleh atau dilakukan melalui perangkat yang selalu standby disaku atau tas pengguna. Latar belakang dari penelitian ini yaitu semakin banyaknya iklan yang ada pada sebuah website atau aplikasi yang terkadang iklan tersebut mengandung sebuah konten yang dapat berdampak buruk bagi pengguna. Oleh karena itu dibuatlah "Aplikasi pemblokir iklan pada browser berbasis android" yang bertujuan untuk menghindarkan pengguna smartphone android dari iklan yang berdampak negatif. Adapun Algoritma yang digunakan adalah Algoritma File Text Merging, yang akan menggabungkan file host yang ada pada internet dengan yang ada pada sistem Android. Hasil dari penelitian ini adalah iklan pada perangkat android akan terblokir pada saat menggunakan aplikasi dan dapat menghindarkan pengguna dari iklan yang berdampak negatif.
\end{abstract}

Kata kunci: android, Website, Mobile, Iklan.

\section{Pendahuluan}

Perkembangan teknologi informasi, khususnya internet yang semakin pesat menyebabkan sulitnya untuk menyaring informasi negatif pada masyarakat. Selain itu masyarakat juga selalu menginginkan segala sesuatunya semakin praktis, salah satunya dengan teknologi mobile. Jumlah penguna teknologi mobile pada akhir tahun mencapai 1,4 miliar pengguna [1]. Sekarang ini telah banyak para konsumen menggunakan smartphone android, sehingga banyak juga para developer Android (pengembang) mendapatkan keuntungan dengan memasang sebuah iklan yang kadang membuat pengguna terganggu dengan iklan yang berada di ponsel android. Akan tetapi iklan tersebut akan muncul ketika smartphone yang terhubung dengan jaringan internet dan sangat mengganggu pengguna yang sedang menggunakan perangkat android tersebut.

Banyak sekali tersedia aplikasi maupun game (permainan) baru yang setiap hari di Submit ke Play Store. Hal ini membuat pengguna ponsel android dimanjakan oleh berbagai macam fitur dan aplikasi yang sangat lengkap hingga fitur-fitur yang ditawarkan memiliki banyak pilihan. Dengan banyaknya aplikasi dan game, pengguna dapat dengan mudah men-download di Play Store secara gratis. Namun ketika hendak menggunakan aplikasi tersebut terdapat pemandangan yang membuat pengguna tidak nyaman, yaitu iklan (Advertisement) dan sering kali iklan tersebut mengandung konten (Pornografi, Perjudian, dan Penipuan) yang berbahaya bagi psikologi pengguna [2].

Aplikasi yang akan dibangun oleh peneliti menggunakan sistem operasi android sebagai platform. Pengguna aplikasi dapat berselancar dengan aman dan nyaman tanpa ada gangguan iklan dan konten berbahaya yang terkandung di dalamnya. Kemudian pengguna juga dapat mengatur jenis iklan apa saja yang ingin ditampilkan [3]. Jenis iklan yang dapat diblokir pada aplikasi ini adalah iklan yang biasa muncul pada saat menggunakan browser, aplikasi maupun game. Harapan dan solusi yang ditawarkan dapat menghindarkan pengguna dari efek negatif sebuah iklan serta memberikan rasa aman pada pengguna ketika sedang melakukan aktifitas pada smartphone android. Penulis menggunakan fitur yang disediakan oleh google dalam memfilter iklan yaitu Google Ads Settings dalam merancang aplikasi pemblokir iklan pada browser dan aplikasi berbasis android.

\section{Metode}

Metode yang digunakan pada penelitian ini yaitu metode air terjun (waterfall) yang terkadang disebut sebagai siklus hidup klasik (classic life cycle), dinamakan hal ini sebab menyiratkan pendekatan yang sistematis dan berurutan (sekuensial). Pada pengembangan perangkat lunak, dimulai dengan spesifikasi kebutuhan pengguna dan berlanjut melalui tahapan-tahapan perencanaan (planning), pemodelan (modeling), konstruksi (contruction), serta penyerahan sistem perangkat lunak ke para pelanggan / pengguna (deployment), yang diakhiri dengan dukungan berkelanjutan pada perangkat lunak lengkap yang telah dihasilkan [8]. Dalam penelitian ini akan dibangun sebuah aplikasi untuk memblokir iklan yang ada pada browser maupun aplikasi pada sistem operasi android. Aplikasi yang dibangun bebasis mobile. Jadi inti dari aplikasi ini adalah mencegah iklan atau konten yang 
mengandung unsur negatif agar tidak tampil pada pengguna yang sedang menggunakan smartphone mereka dan terkoneksi dengan internet.

Gambar 1 menjelaskan sistem yang berjalan selama ini. Di mana pengguna melakukan aktifitas berselancar di internet menggunakan browser pada smartphone android yang tidak memiliki fitur adblocking.

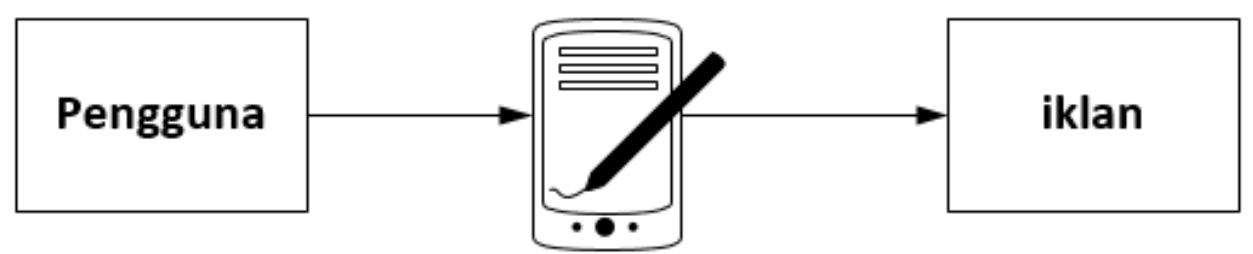

Gambar 1. Alur Pengguna Menggunakan Smartphone

Aplikasi dapat memblokir dan menfilter iklan yang akan tampil pada aplikasi maupun permainanyang menggunakan file host yang berisi URL iklan-iklan yang diduga berbahaya bagi pengguna ketika hendak melakukan aktifitas penggunaan smartphone [4].

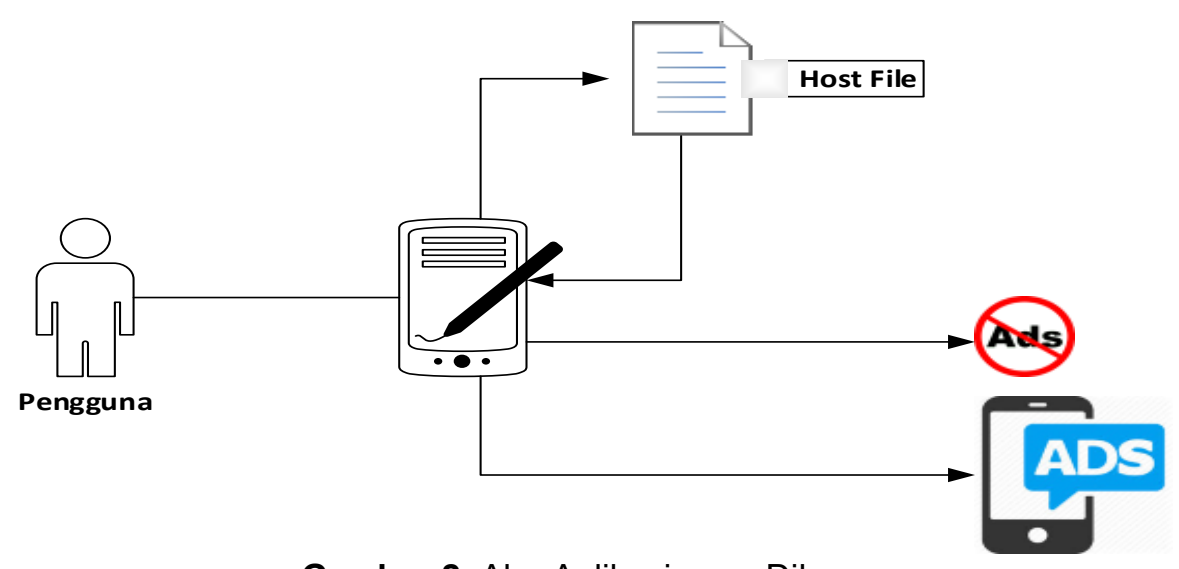

Gambar 2. Alur Aplikasi yang Dibangun

Pada Gambar 2, pengguna menggunakan smartphone android lalu membuka aplikasi, setelah itu pengguna mengaktifkan fitur blokir pada aplikasi, sementara itu aplikasi akan mendownload file host yang ada di internet lalu merangkai dan menggabungkan file host tersebutdengan file host yang ada pada sistem Android. Dengan menggunakan aplikasi, pengguna dapat memblokir atau memilih jenis iklan apa saja yang dapat tampil atau tidak [6].

Proses dimulai ketika user menggunakan aplikasi lalu menekan tombol Apply pada aplikasi maka secara otomatis proses pada aplikasi akan berjalan di belakang layar dan menampilkan tahap-tahap yang berhasil dieksekusi oleh aplikasi. Proses pertama yaitu aplikasi akan meminta hak akses sebagai root pada aplikasi, jika mendapat akses root makaaplikasi akan mengunduh file host yang ada di internet, lalu menguraikan file host tersebut, lalu menggabungkan dengan file host yang ada pada sistem operasi android, lalu membangun file host yang berisi url dari iklan tersebut sehingga siap digunakan oleh aplikasi sebagai penyaring dari iklan atau konten yang berbahaya pada smartphone android [5].

Pada Gambar 3, Sequence diagram pada aplikasi menggambarkan interaksi antara user dengan sistem di mana setiap aksi yang dilakukan oleh user akan direspon oleh aplikasi. Dalam sequence diagram ini diperlihatkan proses yang terjadi sebagai bentuk dari reaksi sistem terhadap aktivitas user. 


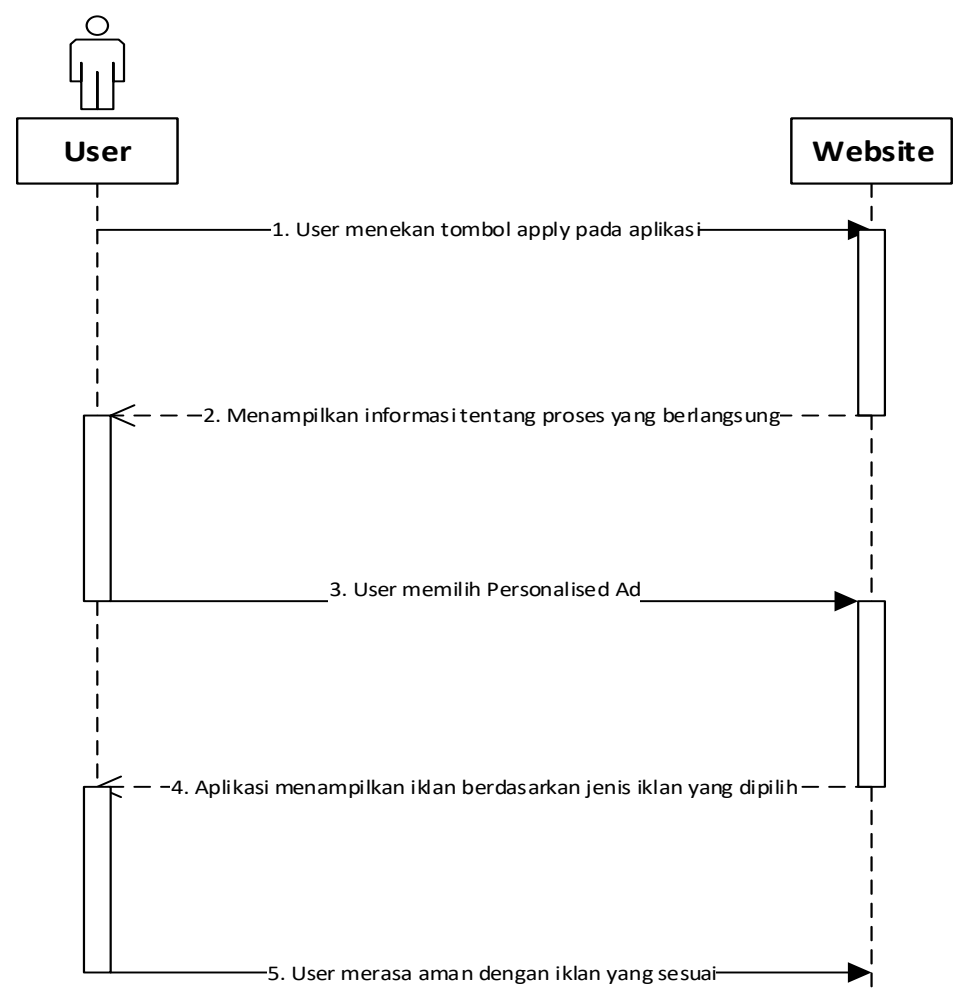

Gambar 3. Gambar Sequence Diagram

\section{Hasil dan Pembahasan}

\subsection{Implementasi Algoritma File Text Merging}

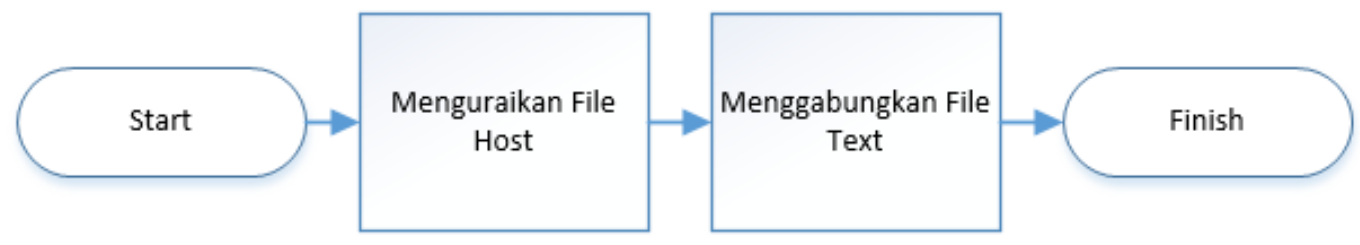

Gambar 4. Bagan Algoritma File Text Merging

Pada Gambar 4, tahap implementasi sistem di awali dengan start kemudian menguraikan file host. Setelah itu menggabungkan file text dan diakhiri dengan finish. Tahap Implementasi menerjemahkan perancangan berdasarkan hasil analisis dalam bahasa yang dapat dimengerti oleh mesin serta penerapan perangkat lunak pada keadaan yang sesungguhnya.

\subsection{Algoritma File Text Merging pada File Host}

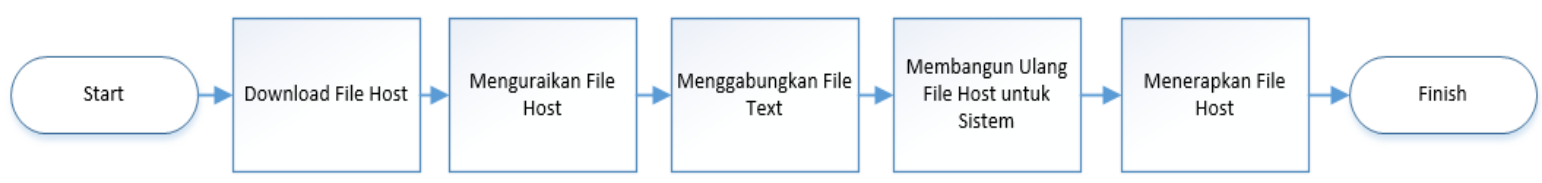

Gambar 5. Bagan Implementasi Algoritma File Text Merging

Pada Gambar 5, tahapan algoritma File Text Merging diawali dengan men-download file host kemudian menguraikan file host, setelah itu menggabungkan dan mulai membangun ulang file host untuk sistem kemudian menerapkan file host tersebut.

Implementasi antarmuka menggambarkan tampilan dari aplikasi yang dibangun yaitu implementasi antarmuka aplikasi pemblokir iklan pada browser Android. Implementasi antarmuka dari aplikasi yang dibangun dapat dilihat pada tabel 1 berikut ini. 
ILKOM Jurnal Ilmiah Volume 9 Nomor 2 Agustus 2017

Tabel 1. Implementasi Antarmuka

\begin{tabular}{|c|c|c|}
\hline Menu & Deskripsi & Nama File \\
\hline Dialog Cek Hak & $\begin{array}{l}\text { Program menampilkan } \\
\text { tampilan dialog peringatan }\end{array}$ & no_root_dialog.xml \\
\hline Frame Main Menu & $\begin{array}{l}\text { Program menampilkan } \\
\text { tampilan halaman awal dari } \\
\text { aplikasi. }\end{array}$ & base_activity.xml \\
\hline Popup Menu Option & $\begin{array}{l}\text { Program menampilkan opsi } \\
\text { menu tambahan }\end{array}$ & base.xml \\
\hline Frame Host Source & $\begin{array}{l}\text { Program menampilkan } \\
\text { tampilan halaman daftar dari } \\
\text { host source }\end{array}$ & host_source_activity.xml \\
\hline Dialog Input Data Host Source & $\begin{array}{l}\text { Program menampilkan } \\
\text { tampilan dialog untuk } \\
\text { menginput data host source }\end{array}$ & list_url_dialog.xml \\
\hline Tampilan proses download file host & $\begin{array}{l}\text { Program menampilkan } \\
\text { tulisan downloading }\end{array}$ & base_fragment.xml \\
\hline $\begin{array}{l}\text { Tampilan proses parsing dan merge file } \\
\text { host. }\end{array}$ & $\begin{array}{l}\text { Program menampilkan } \\
\text { tulisan parsing dan merging } \\
\text { hosts files }\end{array}$ & base_fragment.xml \\
\hline Tampilan proses apply file host & $\begin{array}{l}\text { Program menampilkan } \\
\text { tulisan applying file host }\end{array}$ & base_fragment.xml \\
\hline Tampilan success apply & $\begin{array}{l}\text { Program akan menampilkan } \\
\text { tulisan apply success }\end{array}$ & base_fragment.xml \\
\hline Tampilan awal Google Ads & $\begin{array}{l}\text { Program akan mengarahkan } \\
\text { kehalaman awal dari Google } \\
\text { Ads }\end{array}$ & $\begin{array}{l}\text { https://www.google.com } \\
\text { /settings/u/0/ads/ } \\
\text { authenticated }\end{array}$ \\
\hline $\begin{array}{l}\text { Tampilan pilih topic iklan menggunakan } \\
\text { Google Ads }\end{array}$ & $\begin{array}{l}\text { Program akan mengarahkan } \\
\text { kehalaman pilih topic pada } \\
\text { Google Ads }\end{array}$ & $\begin{array}{l}\text { https://www.google.com } \\
\text { /settings/u/0/ads/ } \\
\text { authenticated }\end{array}$ \\
\hline Tampilan testing aplikasi pada browser & $\begin{array}{l}\text { Program akan memblokir } \\
\text { iklan pada browser sehingga } \\
\text { iklan tidak tampak. }\end{array}$ & $\begin{array}{l}\text { http://www.mangaku. } \\
\underline{\text { web.id }}\end{array}$ \\
\hline
\end{tabular}

\subsection{Antarmuka Menu Pilihan Pop Up}

Pada Gambar 6, tampilan menu option untuk menu pilihan terdapat 2 menu yaitu:

1. Menu Host Sources: pada menu ini akan tampil daftar host source yang tersedia.

2. Menu Open Host File: pada menu ini akan membuka file host yang ada pada sistem.

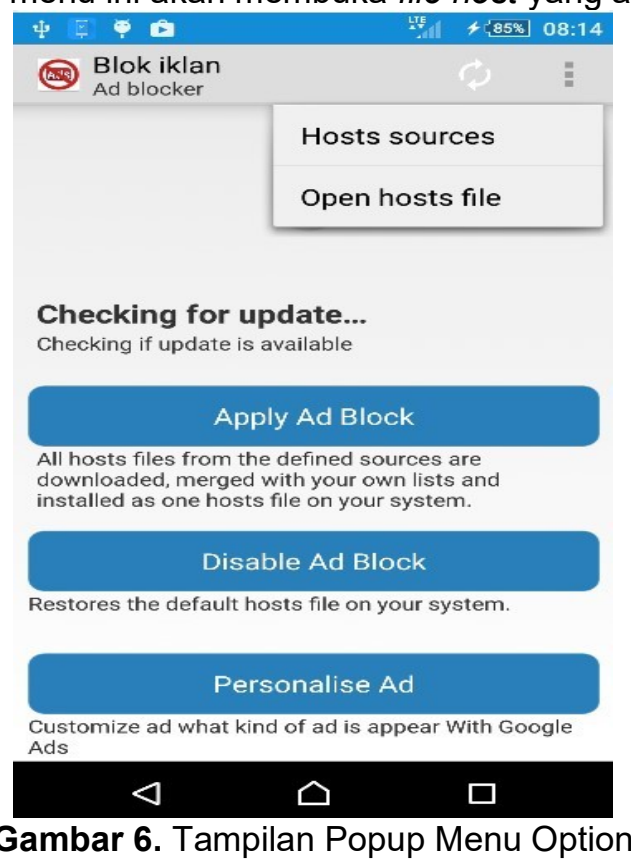




\subsection{Antarmuka Menu Utama Apply Berhasil}

Tampilan ini akan tampil ketika semua proses berhasil dijalankan dan file host siap diterapkan pada browser dan aplikasi.

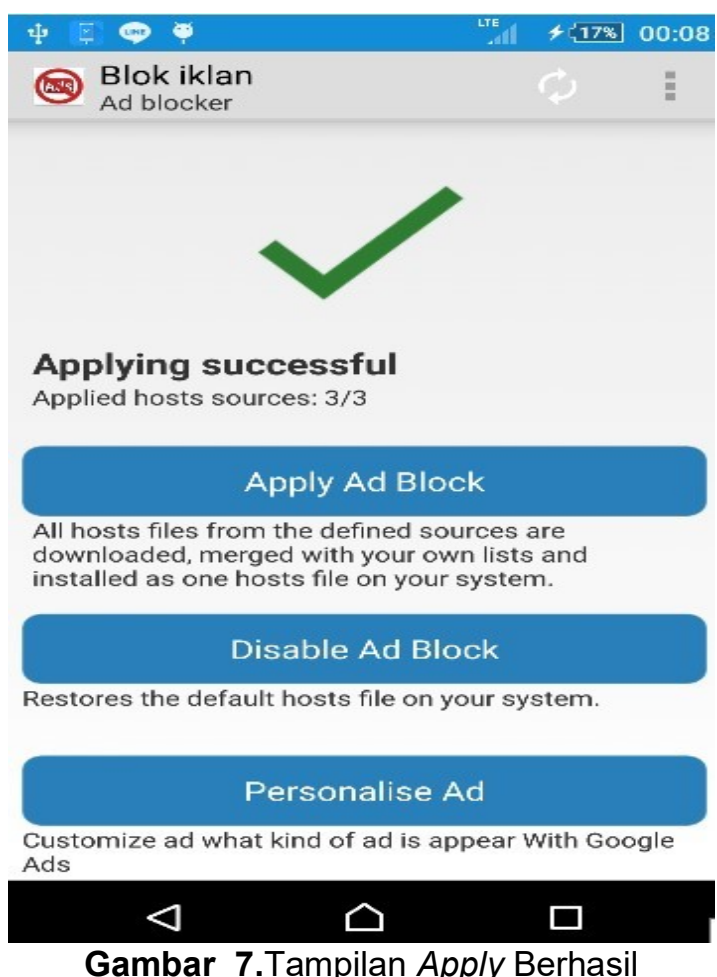

Gambar 7 menjelaskan proses yang terjadi dalam mengunduh file host yang ada pada internet dan berdasarkan list dari file host yang telah ditambahan.

\subsection{Antarmuka Pilih Topik Iklan Pada Google Ads}

Pada Gambar 8 terdapat tampilan di mana pengguna dapat memilih jenis iklan apa saja yang dapat tampil ketika menggunakan aplikasi atau game.

Topik Anda
Bisnis \& Industri
Buku \& Sastra
Game
Game Aksi dan Platform
Game Komputer \& Video
Game Menembak

Gambar 8.Tampilan Pilih Topik Iklan 


\subsection{Antarmuka Sebelum Aplikasi diterapkan}

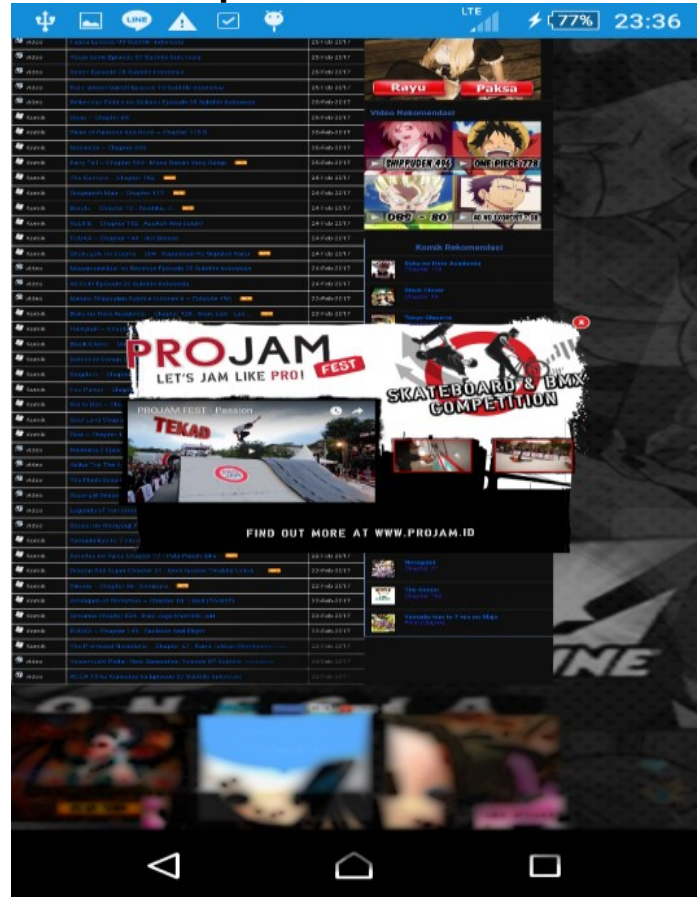

Gambar 9. Tampilan iklan yang diduga mengandung konten negatif pada pengguna

Pada Gambar 9 menunjukkan aplikasi tidak dijalankan dan File host tidak diterapkan. Ketika pengguna membuka situs yang dianggap mengandung konten negatif, iklan dengan mudahnya muncul dan sangat mengganggu pengguna dalam membuka suatu situs.

\subsection{Interface Pengujian Aplikasi pada Browser}

Pada Gambar 10 menunjukkan bahwa iklan pada situs yang dikunjungi pada browser sudah tidak tampil lagi atau telah terblokir. Pada tampilan tersebut penulis mengunjungi situs http://www.mangaku.web.id di mana sebelum menggunakan aplikasi, situs tersebut mempunyai banyak iklan, termasuk iklan yang negatif.

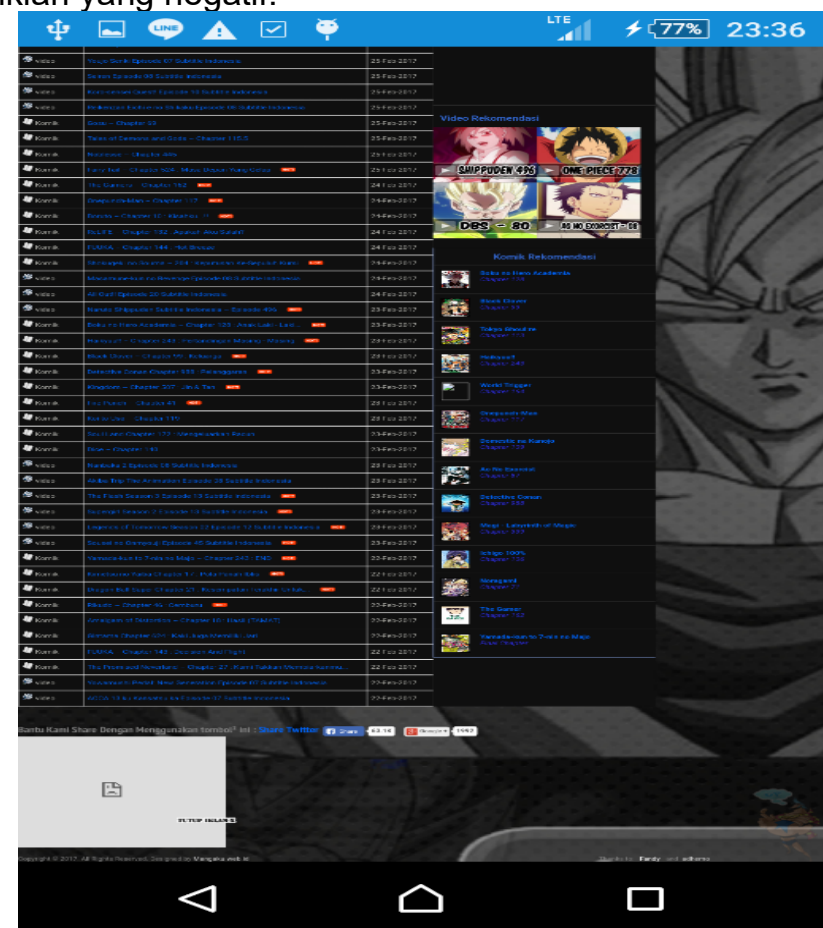

Gambar 10. Tampilan Pengujian Aplikasi pada Browser 


\section{Kesimpulan dan saran}

\subsection{Kesimpulan}

Berdasarkan hasil pembahasan dan analisis aplikasi pemblokir iklan pada browser bebasis android maka peneliti dapat menarik beberapa kesimpulan sebagai berikut:

1. Aplikasi dapat memblokir iklan pada web browser berbasis android.

2. Aplikasi dapat membantu menghindarkan pengguna dari konten negatif yang berbahaya.

3. Aplikasi dalam memblokir iklan menggunakan file host di internet yang di-merge ke dalam file host pada sistem android.

\subsection{Saran}

Setelah melakukan implementasi dan analisa Aplikasi Pemblokir iklan pada browser bebasis android masih terdapat banyak kekurangan. Oleh sebab itu, peneliti menyarakan untuk pengembang selanjutnya antara lain sebagai berikut:

1. Aplikasi Pemblokir iklan pada browser bebasis android dapat lebih disempurnakan lagi dengan menambahkan fitur auto-block pada aplikasi.

2. Aplikasi akan lebih baik lagi jika menggunakan Al (Artificial Intelligent) dalam proses seleksi konten iklan atau konten berbahaya pada iklan di internet.

3. Perlu dilakukan penelitian selanjutnya tentang proses filtering iklan yang ada pada web browser dan aplikasi android.

\section{Daftar Pustaka}

[1] Suryaningrum, F dan Suraya. Rachmawati, Y. 2013. Membangun Jaringan internet Wifi yang sehat di Dinas Pendidikan, Pemuda dan Olahraga Daerah Istimewa Yogyakarta. Journal IST AKPRIND Yogyakarta. Yogyakarta.

[2] Edi, Winarno. 2011. Membuat Sendiri Aplikasi Android Untuk Pemula. Elexmedia Komputindo. Jakarta.

[3] Ardiansyah. 2011. Pengenalan Android Programming. Biraynara. Depok.

[4] Saputro, Hendra. 2007. Pengertian Website dan Unsur-Unsurnya. Andi Offset. Yogyakarta.

[5] Sugiarti, Yuli. 2013. Analisis \& Perancangan UML (Unified Modelling Languange). Graha IImu. Yogyakarta.

[6] Ardiansyah. 2011. Pengenalan Android Programming. Biraynara. Depok.

[7] Safaat, Nazrudin, 2012. Pemprograman Aplikasi Mobile Smartphone dan Tablet PC Berbasis Android. Informatika. Bandung.

[8] Pressman, Roger S. 2012. Rekayasa Perangkat Lunak Pendekatan Praktisi - Edisi 7. Andi. Yogyakarta. 